\title{
Effect of Additives and Process Variables on Enzymatic Hydrolysis of Macauba Kernel Oil (Acrocomia aculeata)
}

\author{
Djéssica Tatiane Raspe, ${ }^{1}$ Lúcio Cardozo Filho, ${ }^{2}$ and Camila da Silva ${ }^{1,3}$ \\ ${ }^{1}$ Program of Post-Graduation in Bioenergy, Maringa State University, UEM, Avenida Colombo 5790, 87020-900 Maringa, PR, Brazil \\ ${ }^{2}$ Department of Chemical Engineering, Maringa State University, UEM, Avenida Colombo 5790, 87020-900 Maringa, PR, Brazil \\ ${ }^{3}$ Department of Technology, Maringá State University, UEM, 87506-370 Umuarama, PR, Brazil
}

Correspondence should be addressed to Camila da Silva; camiladasilva.eq@gmail.com

Received 19 August 2013; Accepted 22 September 2013

Academic Editor: Donald L. Feke

Copyright (C) 2013 Djéssica Tatiane Raspe et al. This is an open access article distributed under the Creative Commons Attribution License, which permits unrestricted use, distribution, and reproduction in any medium, provided the original work is properly cited.

\begin{abstract}
This work investigates the production of free fatty acids (FFAs) from the enzymatic hydrolysis of macauba kernel oil. Experiments evaluate the effect of different enzymes and the addition of salts, surfactants, and solvents to the reaction medium, as well as the effect of process variables. Results showed that FFA yields obtained for use of Lipozyme RM IM were higher than those obtained from Lipozyme TL IM and Lipozyme 435. The addition of salts and surfactants did not promote increased production of FFAs, while adding $n$-hexane and heptane to the reaction medium led to an increased reaction rate. It can be observed for the results that the temperature, water : oil mass ratio, and enzyme percentage had positive effects on the FFA yield in the range of $35^{\circ} \mathrm{C}$ to $55^{\circ} \mathrm{C}$, 1: 20 to $1: 2$, and 1 to $15 \%$, respectively, and that, from these limits, increases in these variables did not cause significant increase in FFA yields. The addition of buffer promoted an increase in yield FFAs, as well as the $\mathrm{pH}$ of the buffer, and it was reported that an agitation of $400 \mathrm{rpm}$ resulted in the highest yields in the investigated range.
\end{abstract}

\section{Introduction}

Currently, the conversion of fats and oils into products with high added value, such as free fatty acids (FFAs) and their derivatives, has been of great commercial interest; these compounds act as essential components in the oleochemical industry [1]. A significant number of products require fatty acids to manufacture in the industrial sector, spurring research into the resolution of racemic mixtures [2], the synthesis of emulsifiers $[3,4]$, the transformation of lipids in order to produce structured lipids with high levels of polyunsaturated fatty acids $[5,6]$, and obtaining bioaromas [7]. Recently, FFAs have been used for biodiesel production [8].

Different oilseeds have been the focus of interest in the agronomic and industrial sectors. Industrial conflict between food and nonfood sources has arisen due to the limited number of options between cultures. One solution would be the introduction of new oilseeds aimed at achieving strategic sectors [9]. The Acrocomia aculeata is considered one of the most obvious species of palm in Brazil $[10,11]$. This species has oleaginous fruits in clusters that may weigh approximately $25 \mathrm{~kg}$ in natural conditions, has recently been considered as a potential feedstock for biodiesel production [12], and can produce 10 times more oil per hectare (ha) than soybean [13]; projections based on suitable agronomic conditions predict that a plantation can produce 16000 to $25000 \mathrm{~kg} \mathrm{ha}^{-1}$ of fruit and $\sim 6200 \mathrm{~kg} \mathrm{ha}^{-1}$ of oil [12].

Triacylglycerol hydrolysis takes place in the organic phase by means of three consecutive, reversible steps, with the formation of diacylglycerols and monoacylglycerols as intermediates, resulting in an FFA molecule at every step and glycerol as byproduct. Processes traditionally employed for FFA production are chemical and enzymatic. The chemical process is characterized by involving high temperatures and pressures, and different reaction times [14]. The products thus obtained are quite varied in nature and purity, acquiring undesirable odors and coloration, and in some cases, the denaturation of constituents may occur [15]. Enzymatic hydrolysis, however, uses normal pressure, requires low 
TABLE 1: Chemical composition of macauba kernel oil.

\begin{tabular}{lc}
\hline Fatty acid & Percentage (\%) \\
\hline Lauric (C12:0) & $0.02 \pm 0.00$ \\
Myristic (C14:0) & $0.12 \pm 0.01$ \\
Palmitic (C16:0) & $11.07 \pm 0.22$ \\
Palmitoleic (C16:1n-7) & $1.50 \pm 0.03$ \\
Stearic (C18:0) & $3.46 \pm 0.03$ \\
Oleic (C18:1n-9) & $19.74 \pm 0.07$ \\
cis-Vaccenic (C18:1n-7) & $0.75 \pm 0.00$ \\
Linoleic (C18:2n-6) & $62.33 \pm 0.15$ \\
Linolenic (C18:3n-3) & $0.33 \pm 0.01$ \\
Arachidic (C20:0) & $0.35 \pm 0.00$ \\
Eicosadienoic (C20:2n-6) & $0.27 \pm 0.00$ \\
\hline
\end{tabular}

power consumption, and provides for obtaining high purity products [16].

The enzymatic hydrolysis process requires two requirements, formation of a lipid/water interface and the absorption of that enzyme in this interface. Thus, with an increase in the interface, more enzyme is adsorbed, resulting in an increased reaction rate $[17,18]$. Previous studies have reported an increased reaction rate with the addition of additives in the reaction medium, such as surfactants $[16,19-21]$ and salts $[6,16,20,22-24]$, in addition to increased enzyme activity in the presence of organic solvents [25-29]. Another interesting finding refers to the effect of process variables on the yield of the hydrolysis reaction, which refers to the evaluation of the effect of temperature, water content, agitation, catalyst percentage, and addition of buffer at different pHs [12, 27, 2933].

In this sense, the main objective of the present work is to investigate the enzymatic hydrolysis of macauba oil for obtaining a hydrolyzate rich in free fatty acids. For this purpose, we assessed the effects of different enzymatic catalysts (Lipozyme RM IM, Lipozyme TL IM, and Lipozyme 435), the addition of additives to the reaction medium (salts and surfactants), the addition of solvents, temperature in the range of $35^{\circ} \mathrm{C}$ to $55^{\circ} \mathrm{C}$, a water to oil mass ratio between $1: 1$ and $1: 20$, a catalyst percentage ranging from 5 to $20 \%$ (relative mass of substrate), a pH buffer from 5.7 to 8.0, and agitation from 400 to $2000 \mathrm{rpm}$.

\section{Materials and Methods}

2.1. Materials. In the hydrolysis reactions were used macauba kernel oil (Cocal Brasil) and sodium phosphate buffer (Neon) prepared as Gomori [34]. The enzymes Lipozyme RM IM, Lipozyme TL IM, and Lipozyme 435 (Novozymes) were used as catalysts. Chemical composition for the macauba kernel oil used in this work is reported in Table 1. The FFA content (mg FFA/100 mg) and water content (wt $\%$, Karl Fischer titration method, DL 50, Mettler-Toledo) were determined to be approximately $23.0 \pm 0.4$ and $0.7 \pm 0.05$, respectively. The salts used were copper chloride (Vetec), calcium chloride (Nuclear), potassium chloride (Nuclear), ammonium chloride (Vetec), sodium chloride (Synth), and magnesium chloride (Synth), and the solvents used were $n$ hexane (Nuclear), heptane (Nuclear), isopropanol (Fmaia), and tert-butanol (Sigma-Aldrich). The surfactants used were Triton X-100 (Sigma-Aldrich) and Tween 80 (Oxiteno). In titration step of the samples, a solution of ethyl ether : ethanol $2: 1(\mathrm{v}: \mathrm{v})$ (Vetec/Nuclear), potassium hydroxide (Nuclear), and phenolphthalein as indicator (Nuclear) was used.

\subsection{Experimental Apparatus and Procedure. Enzymatic} hydrolysis reactions were carried out in a magnetically stirred, jacketed flask $(40 \mathrm{~mL})$ connected to a constant temperature bath (Marconi) for temperature monitoring. Typically, about $16 \mathrm{~g}$ of substrate (vegetable oil and water or buffer) was loaded into the reaction vessel, while the amounts of enzyme and solvents or additives were loaded according to preestablished values. At the end of the reaction, immobilized lipase was removed by vacuum filtration, and products were recovered for further analysis. Samples without enzyme were transferred to sampling flasks and placed in a vacuum oven to evaporate the excess solvent. Finally, samples were refrigerated for subsequent analysis.

2.3. Analytical Method. The percentage of free fatty acid was determined based on the method Ca 5a-40 [35], which is based on acid-base titration using an ethanol solution of potassium hydroxide $(\mathrm{KOH})$ previously standardized $\left(0.1 \mathrm{~mol} \mathrm{~L}^{-1}\right)$ as the titrant. Each sample was titrated in duplicate, and the yield of the hydrolysis reactions was calculated from

$$
\text { FFA yield }(\text { wt } \%)=\frac{\mathrm{FFA}_{t}}{\mathrm{TAG}_{0}} \times 100
$$

where $\mathrm{FFA}_{t}$ corresponds to FFA content produced after the hydrolysis reaction and $\mathrm{TAG}_{0}$ corresponds to the triacylglyceride content present in the macauba kernel oil.

The results are presented in terms of FFA yields and FFA content. Data were subjected to one-way ANOVA, Tukey, and Dunnett tests $(P>0.05)$ to evaluate differences in treatment means and between the percentage of additives compared to the standard (without additives).

\section{Results and Discussion}

3.1. Effect of Different Enzymatic Catalysts and Water to Oil Mass Ratio. The effect of the enzymes Lipozyme RM IM, Lipozyme TL IM, and Lipozyme 435 on the hydrolysis of macauba kernel oil was assessed keeping the temperature fixed at $55^{\circ} \mathrm{C}$, agitation at $400 \mathrm{rpm}$, catalyst percentage (in relation to substrates) at $5 \%$, and the water to oil mass ratio between 1:1 and 1:20 (Figure 1). As can be seen in Figure 1, the highest yields were obtained with the use of the enzyme Lipozyme RM IM for all of the water contents evaluated. It can be seen from Figure 1 that yields in the range of $58 \mathrm{wt} \%$ were obtained with Lipozyme RM IM, whereas for Lipozyme TL IM and Lipozyme 435, produced maximum yields of $29 \mathrm{wt} \%$ and $36 \mathrm{wt} \%$, respectively. 


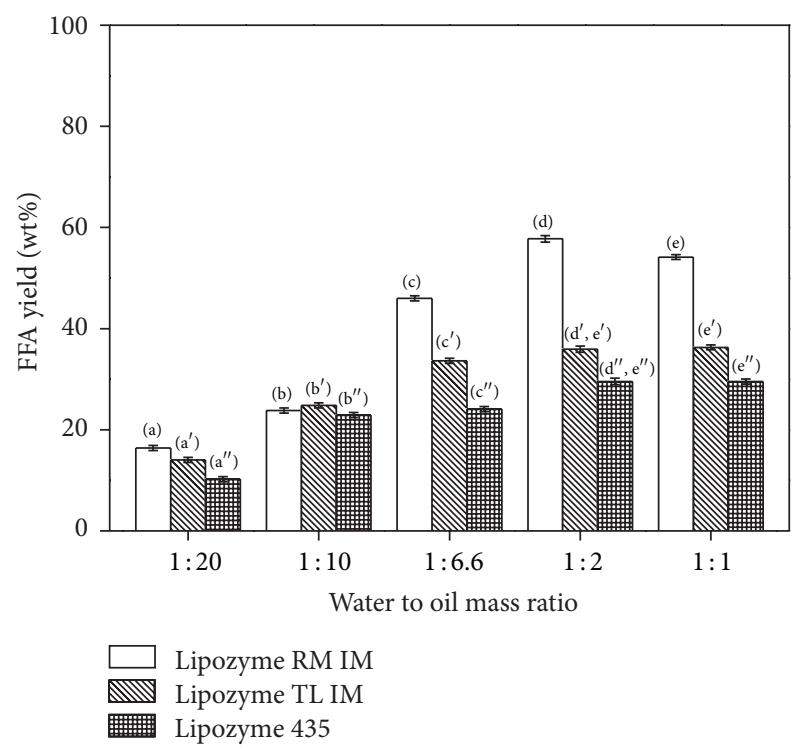

FIGURE 1: Effect of different enzymatic catalysts and water to oil mass ratio in the hydrolysis yield of macauba kernel oil at $55^{\circ} \mathrm{C}, 400 \mathrm{rpm}$, catalyst percentage of $5 \%$, and 6 hours of reaction. Means followed by same letters (for same enzyme) for each column did not differ statistically $(P>0.05)$.

Regarding the amount of water in the reaction medium, Figure 1 shows that the FFA yield increases with an increase proportion of water in the reaction medium in the range of water to oil mass ratio of $1: 20$ to $1: 2$. However, it is noteworthy that when a significant excess of water was applied to the medium (water to oil mass ratio of $1: 1$ ), this had no significant effect on yield $(P>0.05)$, primarily with Lipozyme TL IM and Lipozyme 435, and, in the case of Lipozyme RM IM and Lipozyme 435, lower yields were acquired than for water to oil mass ratio of $1: 2$.

The water content in organic systems is generally limited; however, its presence in any quantity cannot be neglected. Water plays an important role in controlling the performance of enzymes in reaction media, and a small amount is needed for activation of catalysis. However, the amount of water required varies, since the amount of water needed depends on several parameters, including the type and polarity of the solvent, the active site of the enzyme, substrate, the solid support, and the reaction conditions [36].

Cavalcanti-Oliveira et al. [33], in examining the hydrolysis of soybean oil using lipase Thermomyces lanuginosus (liquid), relate that the increase of water in the reaction medium leads to an increase in FFA yield of $14 \%$ for a water to oil mass ratio of $1: 6.6$ to $80 \%$ with a water to oil mass ratio of $1: 2.5$ at $60^{\circ} \mathrm{C}$, with $2.3 \%$ of lipase (relative to the volume of the substrate) and a reaction time of 24 hours. Liu et al. [37], investigating the effect of ultrasound on enzymatic hydrolysis of soybean oil, found that larger amounts of water in the reaction medium increased FFA yield. In the production of natural concentrate of beta-carotene from buriti oil by enzymatic hydrolysis, Ribeiro et al. [38] observed increased FFA yields of $56.6 \%$ to $62.9 \%$ for a water to oil mass ratio of $1: 1.4$ and $1: 2.6$, respectively, at $29^{\circ} \mathrm{C}$ and an enzyme TL IM (immobilized) concentration of $10.7 \mathrm{U}$ (enzyme loading).

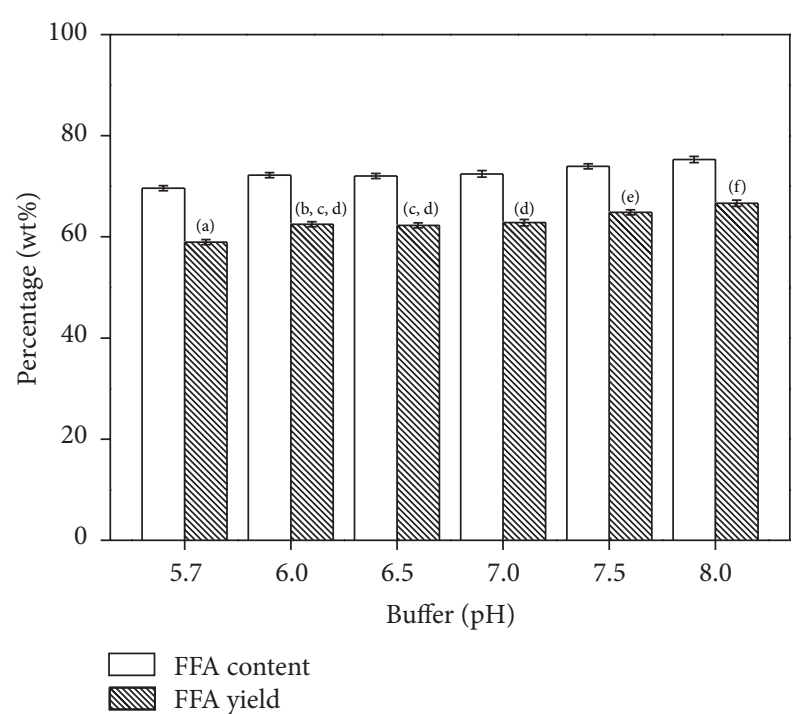

FIGURE 2: Effect of buffer $\mathrm{pH}$ in the hydrolysis yield of macauba kernel oil at $55^{\circ} \mathrm{C}, 400 \mathrm{rpm}$, water to oil mass ratio of $1: 2$, catalyst percentage of $5 \%$, and 6 hours of reaction. Means followed by same letters for each column did not differ statistically $(P>0.05)$.

3.2. Effect of $p H$ Buffer. Reports in the literature indicate that $\mathrm{pH}$ plays an important role in the hydrolysis reaction for obtaining FFA $[27,39]$, and for this reason, the effect of the $\mathrm{pH}$ of the sodium phosphate buffer solution was evaluated in the range of 5.7 to 8.0 with a temperature of $55^{\circ} \mathrm{C}$, agitation of $400 \mathrm{rpm}$, catalyst percentage (relative to mass substrate) of $5 \%$, and water to oil mass ratio of $1: 1$. Figure 2 shows the results obtained for different values of $\mathrm{pH}$ buffer. As can be seen in Figure 2, increasing the $\mathrm{pH}$ leads to an increase in the rate of hydrolysis of triglycerides, reporting yields of $59 \mathrm{wt} \%$ at $\mathrm{pH} 5.7$ and $67 \mathrm{wt} \%$ at $\mathrm{pH}$ 8.0. Comparing the results with those shown in Figure 1, it can be seen that the addition of buffer to the reaction medium increased the yield from $\sim 58 \mathrm{wt} \%$ (for reaction medium with water) to $\sim 67 \mathrm{wt} \%$ at $\mathrm{pH}$ 8.0 .

The Lipozyme RM IM has been used in many cases and has good properties in hydrolysis reactions; that is, using its specificity to liberate FFAs and their activity and stability in unconventional reaction media is one of the advantages of this enzyme, even in this hydrolytic reaction [40]. The $\mathrm{pH}$ of the working medium is an issue in the activity of an enzyme and its selectivity [39]. Hernáiz et al. [41] showed changes in activity in relation to the conformation of the protein to various $\mathrm{pHs}$. The $\mathrm{pH}$ is responsible for opening or blocking the catalytic center [42]. The increased FFA yield by the addition of buffer and $\mathrm{pH}$ increase has been observed in recent studies in the literature $[16,27,28,37]$.

3.3. Effect of Agitation. The effect of agitation was evaluated from 400 to $2000 \mathrm{rpm}$ at temperature of $55^{\circ} \mathrm{C}$, a catalyst percentage (in relation to substrates) of $5 \%$, and a buffer to oil mass ratio of $1: 2$ with results shown in Figure 3. According to Figure 3, in the range of studies evaluated, the best yields were obtained for agitation at $400 \mathrm{rpm}(P>0.05)$. 


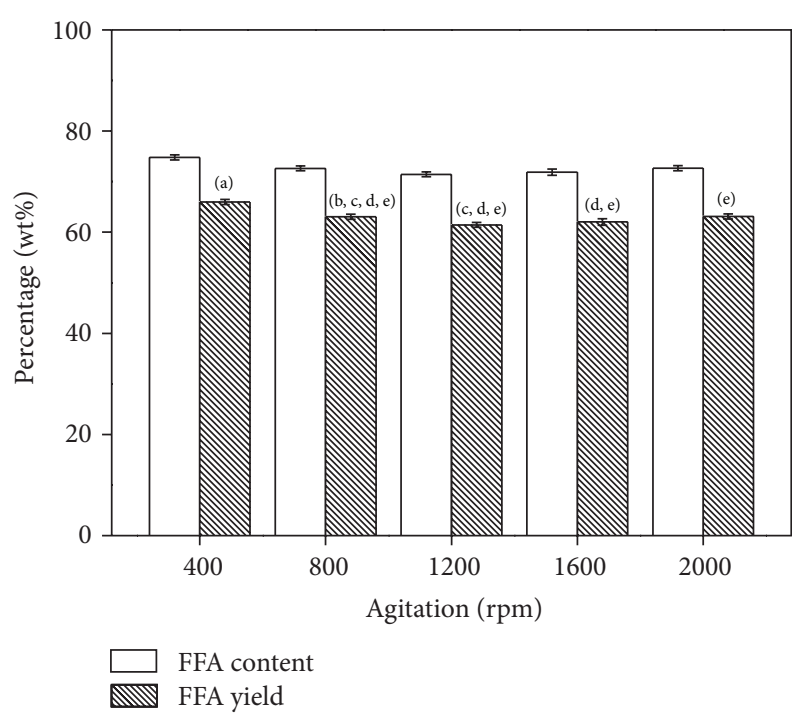

FIGURE 3: Effect of agitation in the hydrolysis yield of macauba kernel oil at $55^{\circ} \mathrm{C}$, buffer to oil mass ratio of $1: 2$, buffer $\mathrm{pH}$ of 8.0 , catalyst percentage of $5 \%$, and 6 hours of reaction. Means followed by same letters for each column did not differ statistically $(P>0.05)$.

Sadana [43] explains that enzymes act efficiently at the stage of interfacial substrates, where the rate of hydrolysis increases with increasing contact surface. Increased agitation of the reaction medium promotes an increase in the number of droplets in the medium, leading to an increased yield of the hydrolysis reaction. In contrast, the agitation causes the exposure of the enzyme to shear stress, denaturing its surface, which leads to its inactivation and thus decreases hydrolysis yield. It is noteworthy, however, that, under low agitation, the effect of increasing the interfacial area of substrate hydrolysis is greater than the effect of inactivation of the enzyme [16, 31], which may explain the results obtained in this study, in which the lowest agitation was more efficient in terms of FFA yield. A similar effect was observed by Babicz et al. [44], which evaluated agitation ranges from 400 to $1300 \mathrm{rpm}$ in the hydrolysis of soybean oil with Lipozyme RM IM (immobilized) and reported yields of $19 \%$ at $700 \mathrm{rpm}$, $400 \mathrm{rpm}$ at $16 \%$, and $9 \%$ at $1300 \mathrm{rpm}$.

3.4. Effect of Surfactants and Salts Addition. Table 2 shows the results of the hydrolysis of macauba kernel oil conducted in the presence of additives in the reaction medium. The effect of the addition of two surfactants (Triton X-100 and Tween 80 ) and six salts was evaluated. As can be seen in Table 2, both surfactants caused a decrease in FFA production. For the use of Triton X-100, the maximum yield of $60 \mathrm{wt} \%$ was obtained at $5 \%$, while adding $10 \%$ Tween 80 resulted in a yield of $\sim 60.6 \mathrm{wt} \%$. The reaction without addition of surfactants showed a yield of $67.3 \mathrm{wt} \%$.

Goswami et al. [16] evaluated the effect of different surfactants in obtaining erucic acid and related 55\% of FFA for reaction without surfactant at $35^{\circ} \mathrm{C}, 10 \mathrm{mg}$ lipase $\mathrm{g}^{-1}$ of oil, $900 \mathrm{rpm}, 6$ hours of reaction, and $3.8 \%$ and $8.76 \%$ with the addition of Triton X-100 and Tween 80 in the reaction
TABLE 2: Effect of additives in the hydrolysis yield of macauba kernel oil at $55^{\circ} \mathrm{C}, 400 \mathrm{rpm}$, buffer to oil mass ratio of $1: 2$, buffer $\mathrm{pH}$ of 8.0, catalyst percentage of $5 \%$, and 6 hours of reaction.

\begin{tabular}{lccc}
\hline & Additives & $\begin{array}{c}\text { Percentage } \\
(\%)\end{array}$ & Yield (wt\%) \\
\hline & Without & 0 & $67.30 \pm 0.19^{\mathrm{A}}$ \\
\hline & & 5 & $60.00 \pm 0.09^{\mathrm{B} ; \mathrm{a}, \mathrm{e}}$ \\
Surfactant & Triton X-100 & 10 & $45.89 \pm 0.08^{\mathrm{C} ; \mathrm{b}}$ \\
(in relation to & & 15 & $43.88 \pm 0.74^{\mathrm{D} ; \mathrm{c}}$ \\
mass substrate) & & 5 & $57.01 \pm 0.19^{\mathrm{E} ; \mathrm{d}}$ \\
& Tween 80 & 10 & $60.58 \pm 0.03^{\mathrm{F} ; \mathrm{e}}$ \\
& & 15 & $58.33 \pm 0.00^{\mathrm{G} ; \mathrm{f}}$ \\
\hline & $\mathrm{CuCl}_{2}$ & & $58.63 \pm 0.30^{\mathrm{H} ; \mathrm{a}^{\prime}, \mathrm{d}^{\prime}}$ \\
& $\mathrm{CaCl}_{2}$ & & $61.77 \pm 0.04^{\mathrm{I} ; \mathrm{b}^{\prime}, \mathrm{c}^{\prime}, \mathrm{d}^{\prime}}$ \\
& $\mathrm{KCl}^{\text {Salts }}$ & $0.01 \mathrm{M}$ in & $62.65 \pm 0.26^{\mathrm{j} ; \mathrm{A} ; \mathrm{c}^{\prime}, \mathrm{d}^{\prime}, \mathrm{f}^{\prime}}$ \\
& $\mathrm{NH}_{4} \mathrm{Cl}$ & buffer & $61.06 \pm 0.09^{\mathrm{K} ; \mathrm{d}^{\prime}}$ \\
& $\mathrm{NaCl}$ & & $68.07 \pm 0.05^{\mathrm{L}, \mathrm{A} ; \mathrm{e}^{\prime}}$ \\
& $\mathrm{MgCl}_{2}$ & & $65.07 \pm 0.11^{\mathrm{M}, \mathrm{A} ; \mathrm{f}^{\prime}}$ \\
\hline
\end{tabular}

Means followed by same uppercase letters (compared with the sample without additives) and lowercase letters (for same additives) did not differ statistically $(P>0.05)$.

medium, respectively. Comparatively, obtaining of FFAs for solid acid catalysts has been evaluated, such as Fe-Zn DMC in the work of Satyarthi et al. [45], who report that the addition of Triton X-100 also reduced the yield of hydrolysis to $8.8 \%$, while hydrolysis without surfactant addition showed yield of $45.7 \%$.

As shown in Table 2, the presence of salts in the reaction medium resulted in a decrease in the yield. Only the addition of $\mathrm{NaCl}$ showed an increase; however, it shows no significant difference $(P>0.05)$ compared to reaction without salt addition. Sharon et al. [22] evaluated the effect of different metal salts on the hydrolysis of castor oil by Pseudomonas aeruginosa KKA-5 (liquid) and found that the residual activity of lipase was decreased by the addition of metals to the reaction medium. The control showed $100 \%$ activity in the absence of metal, changing to activities of $81.5 \%, 70.0 \%$, $77.7 \%, 95.6 \%$, and $73.3 \%$ when added metallic salts of $\mathrm{Na}, \mathrm{K}$, $\mathrm{Cu}, \mathrm{Ca}$, and $\mathrm{Al}$, respectively. Goswami et al. [16] evaluated the presence of salts in the reaction medium of hydrolysis, in which it was noted that, in the absence of salt, a yield of $37.46 \%$ was obtained, and the addition of ions $\mathrm{Na}^{+}, \mathrm{Mg}^{2+}$, and $\mathrm{Ca}^{2+}$ increased the yields to $45 \%, 84.35 \%$, and $65.36 \%$, respectively.

3.5. Effect of Solvent Addition. Figure 4 shows that the results of the effect of the addition of different solvents on the FFA yield for reactions conducted at $55^{\circ} \mathrm{C}$, oil to solvent mass ratio of $1: 1$, a catalyst percentage (relative to substrate) of $5 \%$, a buffer to oil mass ratio of $1: 2$, and a $\mathrm{pH}$ of 8.0 were evaluated as solvents $n$-hexane, $n$-heptane, isopropanol, and tert-butanol. According to Figure 4, from the solvents evaluated, $n$-hexane and $n$-heptane led to increased hydrolysis yields, and isopropanol and tert-butanol led to reduced yields. The best performance was obtained by $n$-hexane, which 


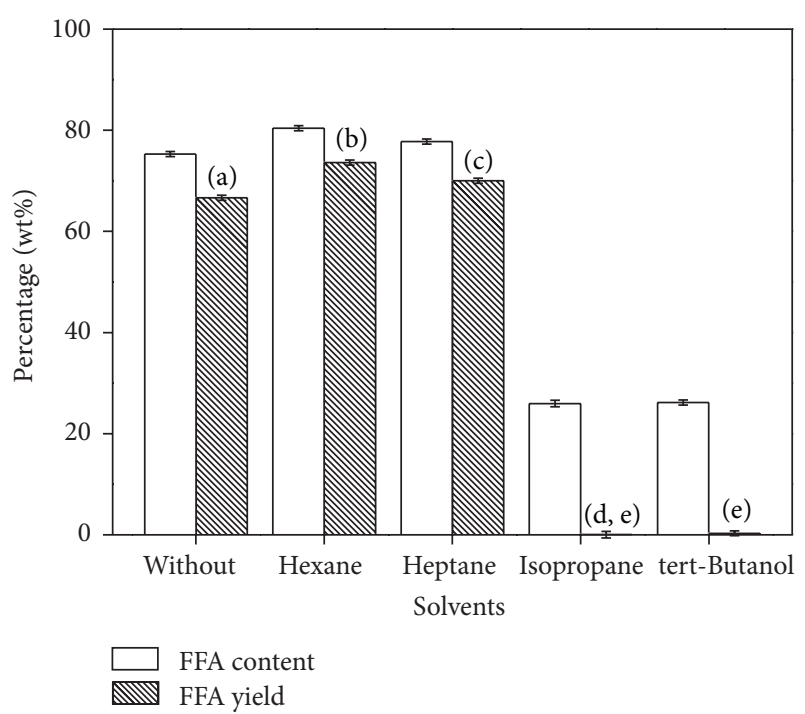

FIGURE 4: Effect of addition of solvents in the hydrolysis yield of macauba kernel oil at $55^{\circ} \mathrm{C}$, oil to solvent mass ratio of $1: 1,400 \mathrm{rpm}$, buffer to oil mass ratio of $1: 2$, buffer $\mathrm{pH}$ of 8.0 , catalyst percentage of $5 \%$, and 6 hours of reaction. Means followed by same letters for each column did not differ statistically $(P>0.05)$.

promoted an increase of 7\% in the reaction yield. It has been reported that the activity of enzymes is shown to be more efficient in the presence of different organic solvents. Solvents such as isooctane $[16,26]$ and $n$-hexane $[46,47]$ have been successfully used in enzymatic reactions that obtain high yields of FFA. Batistella et al. [48] reported an increase in enzymatic activity of Lipozyme RM IM (immobilized) when being in contact with the solvents $n$-hexane and isooctane.

Solvents are normally used in hydrolysis reactions of vegetable oils because they increase the reaction rate, decrease oil viscosity, ease emulsification, and increase the interfacial area that promotes the reaction [32]. Rathod and Pandit [32] evaluated the effect of various solvents (methanol, $n$-hexane, acetone, and isooctane) in FFA production from castor oil by lipase of Aspergillus oryzae (liquid), in which, except for the solvent isooctane, all the other solvents used inhibit the activity of lipase. Kwon et al. [49], conducting synthesis of medium-chain glyceride by Candida rugosa (liquid) in organic solvent, found a significant increase in the reaction yield using $n$-hexane as a solvent.

In a general way, for optimization of biocatalytic systems in organic solvents, $\log P$ is considered a good quantitative method since it represents the polarity of the solvent. The following classification is recommended for choosing the most adequate organic solvents for enzymatic catalysis: (1) solvents with $\log P<2$, due to its high polarity, can cause the denaturation of the catalyst; (2) solvents with $2<\log P>$ 4 are considered moderate; and (3) solvents with $\log P>$ 4 can be considered the most appropriate since they are nonpolar [36, 48, 50,51]. Chua and Sarmidi [36] reported that another important factor is the water content in the organic solvent, which is usually very limited. However, the presence of any quantity of water cannot be neglected, since it plays an important role in controlling the performance of the enzyme

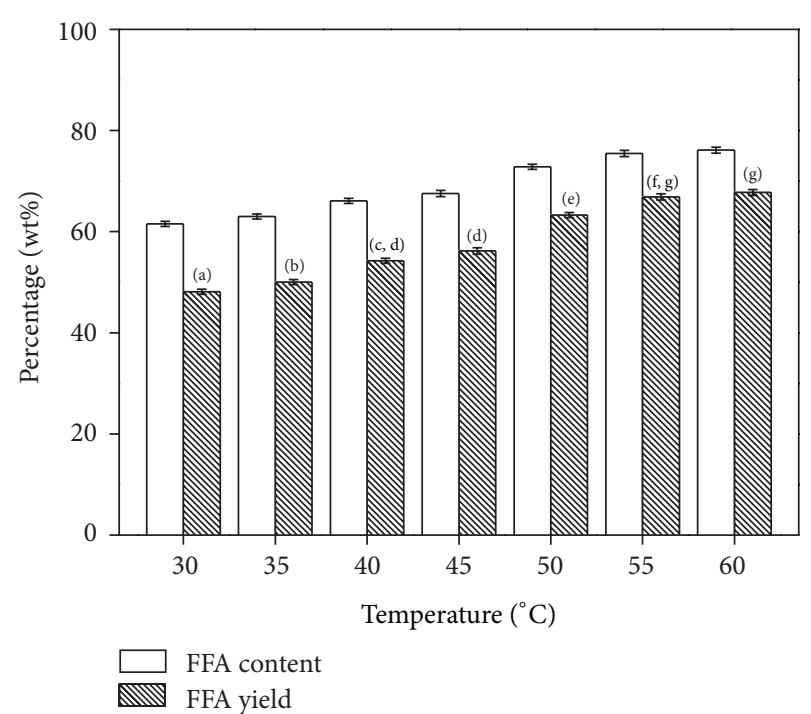

FIGURE 5: Effect of temperature in the hydrolysis yield of macauba kernel oil at $400 \mathrm{rpm}$, buffer to oil mass ratio of $1: 2$, buffer $\mathrm{pH}$ of 8.0, catalyst percentage of $5 \%$, and 6 hours of reaction. Means followed by same letters for each column did not differ statistically $(P>0.05)$.

in organic medium, but there is no principle to guide the selection of the organic solvent to enzymatic processes in particular. The only criterion is the degree of compatibility of the solvent with the maintenance of activity and stability of enzyme [36].

In this work, $n$-hexane $(\log P=3.5)$ was shown to be the most suitable organic solvent for the hydrolysis of macauba kernel oil, leading to FFA yields of $73.58 \mathrm{wt} \%$, followed by heptane $(\log P=4.0)$ with $70 \mathrm{wt} \%$. This reaction, conducted with isopropanol and tert-butanol $\log P=0.05$ and $\log P=$ 0.35 , resp.), produced yields of $0.3 \%$. This result may be related to the fact that solvents with high polarity can remove water molecules from the enzyme, so that the enzyme does not get sufficient water to maintain its active configuration [52].

3.6. Effect of Temperature. Figure 5 shows the effect of temperature evaluated in the range of 30 to $60^{\circ} \mathrm{C}$, at $400 \mathrm{rpm}$, buffer to oil mass ratio of $1: 2$, and catalyst percentage (in relation to substrates) of 5\%. From Figure 5, it can also be noted that increasing the temperature increases the yield of FFA in the range of 30 to $55^{\circ} \mathrm{C}$. A similar effect was observed by Phuah et al. [53] in investigating the effect of temperature on the hydrolysis of partial palm oil catalyzed by Lipozyme RM IM (immobilized) in the range of 45 to $55^{\circ} \mathrm{C}$. Avelar et al. [24] evaluated the hydrolysis of vegetable oils and reported that the increase in temperature causes increase in FFA yields, obtaining yield of $81 \%$ at $25^{\circ} \mathrm{C}$, whereas at $50^{\circ} \mathrm{C}$, hydrolysis was complete.

The thermostability of enzyme to different values of temperature is an important parameter for the use of enzymes in the hydrolysis of triacylglycerols. It is known that the kinetic properties and stability of the enzymes may vary significantly, depending on their origin, test conditions, incubation time, 


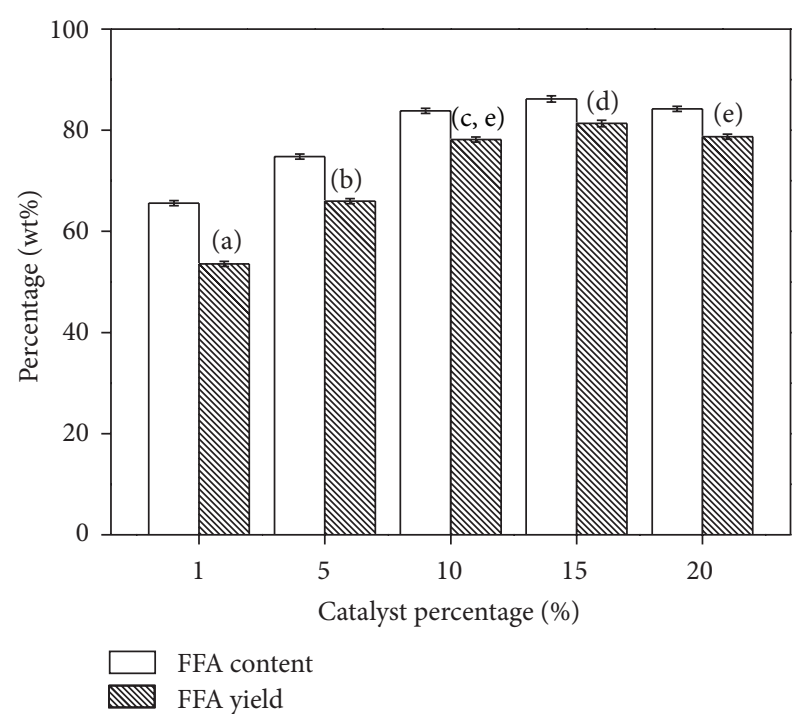

FIGURE 6: Effect of catalyzed percentage in the hydrolysis yield of macauba kernel oil at $55^{\circ} \mathrm{C}, 400 \mathrm{rpm}$, buffer to oil mass ratio of $1: 2$, buffer $\mathrm{pH}$ of 8.0 , and 6 hours of reaction. Means followed by same letters for each column did not differ statistically $(P>0.05)$.

$\mathrm{pH}$, temperature, the method, and substrates used, which makes comparison difficult [54].

3.7. Effect of Catalyst Percentage. Enzyme concentration has a strong impact on the catalytic process because the concentration of enzyme in the reaction medium causes it to move from the aqueous phase into the interface at an increasing rate; therefore, increasing its interaction with substrates leads to increased rates of hydrolysis [16]. Figure 6 shows the results of experiments carried out by varying the catalyst concentration from 1 to $20 \%$ (relative to oil mass) obtained at $55^{\circ} \mathrm{C}, 400 \mathrm{rpm}$, with a buffer to oil mass ratio of $1: 2$, and buffer $\mathrm{pH}$ of 8.0. One can observe from Figure 6 that an increase in the catalyst percentage led to a sharp increase in FAA yield of $54 \mathrm{wt} \%$ to $\sim 82 \mathrm{wt} \%$. For example, with an enzyme percentage of $5 \%$, a yield on the order of $66 \mathrm{wt} \%$ was obtained, while $78 \mathrm{wt} \%$ was obtained with addition of an enzyme percentage of $10 \%$ in the reaction medium. An increasing reaction rate parallel to the increase in the concentration of the catalyst can be seen from results with 10 and $15 \%$, although it is not significant $(P>$ 0.05 ). This is possibly due to the saturation of the enzyme at the interface between oil and aqueous phase, in which an increase in enzyme concentration provided no significant changes in the reaction rate [55].

The increase in reaction rate with an increase in enzyme content was also observed by Freitas et al. [6], who reported hydrolysis with $35 \%$ of FFA after 24 hours with the reaction temperature at $40^{\circ} \mathrm{C}$ and agitation at $200 \mathrm{rpm}$. The percentage of Candida rugosa (crude form) reported by the authors varied from 1 to $3 \%$ (relative to oil mass), where the percentage of $3 \%$ corresponded to greater yield. A similar effect was observed by Meng et al. [56] for the hydrolysis of soybean oil with Yarrowia lipolytica (immobilized), which we assessed to have enzyme concentrations of 25 to $100 \mathrm{Uw} \mathrm{g}^{-1}$ of oil; yields of approximately $90 \%$ have been reported for the highest amount of enzyme.

In this study, a $\sim 82 \mathrm{wt} \%$ yield of FFA was obtained at 6 hours of reaction, a buffer to oil mass ratio $1: 2$, a temperature of $55^{\circ} \mathrm{C}$, agitation of $400 \mathrm{rpm}$, phosphate buffer solution $(\mathrm{pH}$ 8.0 ), and a catalyst percentage of $15 \%$. Appreciable yields $(80 \%)$ were reported by Cavalcanti-Oliveira et al. [33], using a buffer to oil mass ratio of $1: 2, \mathrm{pH} 8.0$, and $50^{\circ} \mathrm{C}$ for 24 hours using $2.3 \%$ of the catalyst Thermomyces lanuginosus (liquid). Goswami et al. [16] reported a 37.46\% yield of FFA from hydrolysis of mustard oil after 6 hours, buffer to oil mass ratio of $1: 1, \mathrm{pH}$ of $9.0,900 \mathrm{rpm}$, and an enzyme pancreas lipase concentration of $1 \%$ (from oil mass).

\section{Conclusions}

This work reported experimental data on FFA production from macaw kernel oil obtained by enzymatic hydrolysis. Results reported that RM IM is more efficient for conducting this reaction. In the experimental range investigated, it was verified that temperature and $\mathrm{pH}$ had a positive effect on FFA yield, while increasing agitation showed no significant increase, and the catalyst percentage and the water to oil mass ratio had a positive effect within a given study range. The addition of salts and surfactants to the reacting system of hydrolysis macaw oil was not efficient in increasing the reaction rate in the conditions considered $(P>0.05)$. The presence of $n$-hexane and heptane in the reaction medium increased the FFA yield. For the results obtained, appreciable yields $(\sim 82 \mathrm{wt} \%)$ were achieved at $55^{\circ} \mathrm{C}$, buffer to oil mass ratio of $1: 2, \mathrm{pH} 8.0,15 \%$ of enzyme, $400 \mathrm{rpm}$, and 6 hours of reaction.

\section{Acknowledgments}

The authors thank CNPq, CAPES, and Fundação Araucária for the financial support and Maringa State University (UEM) for the scholarship.

\section{References}

[1] J. Huang, Y. Liu, Z. Song, Q. Jin, Y. Liu, and X. Wang, "Kinetic study on the effect of ultrasound on lipase-catalyzed hydrolysis of soy oil: study of the interfacial area and the initial rates," Ultrasonics Sonochemistry, vol. 17, no. 3, pp. 521-525, 2010.

[2] S. S. Kaki and P. Adlercreutz, "Quantitative analysis of enzymatic fractionation of multiple substrate mixtures," Biotechnology and Bioengineering, vol. 110, no. 1, pp. 78-86, 2013.

[3] I. I. Junior, M. C. Flores, F. K. Sutili et al., "Fatty acids residue from palm oil refining process as feedstock for lipase catalyzed monoacylglicerol production under batch and continuous flow conditions," Journal of Molecular Catalysis B, vol. 77, pp. 53-58, 2012.

[4] I. Itabaiana Jr, F. K. Sutili, S. G. F. Leite et al., "Continuous flow valorization of fatty acid waste using silica-immobilized lipases," Green Chemistry, vol. 15, no. 1, pp. 518-524, 2013.

[5] O. W. D. Gamboa and L. A. Gioielli, "Comportamento de Cristalização de Lipídios estruturados obtidos a partir de 
gordura de palmiste e óleo de peixe," Química Nova, vol. 29, no. 4, pp. 646-653, 2006.

[6] L. Freitas, T. Bueno, V. H. Perez, J. C. Santos, and H. F. De Castro, "Enzymatic hydrolysis of soybean oil using lipase from different sources to yield concentrated of polyunsaturated fatty acids," World Journal of Microbiology and Biotechnology, vol. 23, no. 12, pp. 1725-1731, 2007.

[7] N. Paroul, L. P. Grzegozeski, V. Chiaradia et al., "Solventfree production of bioflavors by enzymatic esterification of citronella (Cymbopogon winterianus) essential oil," Applied Biochemistry and Biotechnology, vol. 166, no. 1, pp. 13-21, 2012.

[8] P. Goyal, M. P. Sharma, and S. Jain, "Optimization of conversion of high free fatty acid Jatropha curcas oil to biodiesel using response surface methodology," ISRN Chemical Engineering, vol. 2012, Article ID 327049, 8 pages, 2012.

[9] D. C. Lopes and A. J. Steidle-Neto, "Potential crops for biodiesel production in Brazil: a review," World Journal of Agricultural Sciences, vol. 7, no. 2, pp. 206-217, 2011.

[10] P. E. Motta, A. T. Oliveira Filho, and J. B. V. Gomes, "Ocorrência da Macaúba em Minas Gerais: relação com atributos climáticos, pedológicos e vegetacionais," Pesquisa Agropecuária Brasileira, vol. 37, no. 7, pp. 1023-1031, 2002.

[11] J. A. Ratter, S. Bridgewater, and J. F. Ribeiro, "Analysis of the floristic composition of the Brazilian cerrado vegetation III: comparison of the woody vegetation of 376 areas," Edinburgh Journal of Botany, vol. 60, no. 1, pp. 57-109, 2003.

[12] T. P. Pires, E. S. Souza, K. N. Kuki, and S. Y. Motoike, "Ecophysiological traits of the macaw palm: a contribuition towards the domestication of a novel oil crop," Industrial Crops and Products, vol. 44, no. 1, pp. 200-210, 2013.

[13] R. Roscoe, A. Richetti, and E. Maranho, "Análise de viabilidade técnica de oleaginosas para produção de biodiesel em Mato Grosso do Sul," Revista Política Agricola, vol. 16, no. 1, pp. 48-59, 2007.

[14] J. S. S. Pinto and F. M. Lança, "Hidrólise do Óleo de Azadirachta indica em água subcrítica e determinação da composição dos triacilglicerídeos e ácidos graxos por cromatografia gasosa de alta resolução e alta temperatura e cromatografia gasosa de alta resolução acoplada à espectrometria de massas," Química Nova, vol. 33, no. 2, pp. 394-397, 2010.

[15] D. Goswami, R. Sen, J. K. Basu, and S. De, "Surfactant enhanced ricinoleic acid production using Candida rugosa lipase," Bioresource Technology, vol. 101, no. 1, pp. 6-13, 2010.

[16] D. Goswami, J. K. Basu, and S. De, "Optimal hydrolysis of mustard oil to erucic acid: a biocatalytic approach," Chemical Engineering Journal, vol. 181-182, pp. 542-548, 2012.

[17] H. F. De Castro, A. A. Mendes, J. C. Dos Santos, and C. L. De Aguiar, "Modification of oils and fats by biotransformation," Química Nova, vol. 27, no. 1, pp. 146-156, 2004.

[18] A. A. Mendes and H. Ferreira De Castro, "Effect on the enzymatic hydrolysis of lipids from dairy wastewater by replacing Gum Arabic emulsifier for sodium chloride," Brazilian Archives of Biology and Technology, vol. 48, pp. 135-142, 2005.

[19] P. Skagerlind, M. Jansson, B. Bergenståhl, and K. Hult, "Binding of Rhizomucor miehei lipase to emulsion interfaces and its interference with surfactants," Colloids and Surfaces B, vol. 4, no. 3, pp. 129-135, 1995.

[20] M. Persson, I. Mladenoska, E. Wehtje, and P. Adlercreutz, "Preparation of lipases for use in organic solvents," Enzyme and Microbial Technology, vol. 31, no. 6, pp. 833-841, 2002.
[21] J. K. Satyarthi, D. Srinivas, and P. Ratnasamy, "Estimation of free fatty acid content in oils, fats, and biodiesel by $1 \mathrm{H}$ NMR spectroscopy," Energy and Fuels, vol. 23, no. 4, pp. 2273-2277, 2009.

[22] C. Sharon, M. Nakazato, H. I. Ogawa, and Y. Kato, "Lipaseinduced hydrolysis of castor oil: effect of various metals," Journal of Industrial Microbiology \& Biotechnology, vol. 21, no. 6, pp. 292-295, 1998.

[23] M. T. Ru, J. S. Dordick, J. A. Reimer, and D. Clark D, "Optimizing the salt-induced activation of enzymes in organic solvents," Biotechnology Bioengineering, vol. 63, no. 2, pp. 233241, 1999.

[24] M. H. M. Avelar, D. M. J. Cassimiro, K. C. Santos, R. C. C. Domingues, H. F. Castro, and A. A. Mendes, "Hydrolysis of vegetable oils catalyzed by lipase extract powder from dormant castor bean seeds," Industrial Crops and Products, vol. 44, no. 1, pp. 452-458, 2013.

[25] S. R. Kulkarni and A. B. Pandit, "Enzymatic hydrolysis of castor oil: an approach for rate enhancement and enzyme economy," Indian Journal of Biotechnology, vol. 4, no. 2, pp. 241-245, 2005.

[26] M. S. Puthli, V. K. Rathod, and A. B. Pandit, "Enzymatic hydrolysis of castor oil: process intensification studies," Biochemical Engineering Journal, vol. 31, no. 1, pp. 31-41, 2006.

[27] N. A. Serri, A. H. Kamarudin, and S. N. Abdul Rahaman, "Preliminary studies for production of fatty acids from hydrolysis of cooking palm oil using C. rugosa lipase," Journal of Physical Science, vol. 19, no. 1, pp. 79-88, 2008.

[28] M. M. R. Talukder, J. C. Wu, N. M. Fen, and Y. L. S. Melissa, "Two-step lipase catalysis for production of biodiesel," Biochemical Engineering Journal, vol. 49, no. 2, pp. 207-212, 2010.

[29] C. Sharma, P. Satyendra, A. Chaurasiab, and K. Dalai, "Enzymatic hydrolysis of cod liver oil for the fatty acids production," Catalysis Today, vol. 207, no. 1, pp. 93-100, 2013.

[30] W. J. Ting, K. Y. Tung, R. Giridhar, and W. T. Wu, "Application of binary immobilized Candida rugosa lipase for hydrolysis of soybean oil," Journal of Molecular Catalysis B, vol. 42, no. 1-2, pp. 32-38, 2006.

[31] D. Goswami, J. K. Basu, and S. De, "Optimization of process variables in castor oil hydrolysis by Candida rugosa lipase with buffer as dispersion medium," Biotechnology and Bioprocess Engineering, vol. 14, no. 2, pp. 220-224, 2009.

[32] V. K. Rathod and A. B. Pandit, "Effect of various additives on enzymatic hydrolysis of castor oil," Biochemical Engineering Journal, vol. 47, no. 1-3, pp. 93-99, 2009.

[33] E. A. Cavalcanti-Oliveira, P. R. Da Silva, A. P. Ramos, D. A. G. Aranda, and D. M. G. Freire, "Study of soybean oil hydrolysis catalyzed by Thermomyces lanuginosus lipase and its application to biodiesel production via hydroesterification," Enzyme Research, vol. 2011, Article ID 618692, 8 pages, 2011.

[34] G. Gomori, "Preparation of buffers for use in enzyme studies," in "Methods in Enzymology, S. P. Colowick and N. O. Kaplan, Eds., vol. 1, Academic Press, New York, NY, USA, 1955.

[35] AOCS, American Oil Chemists' Society, Official Methods and Recommended Practices, vol. 2, Champaign, Ill, USA, 4th edition, 1998.

[36] L. S. Chua and M. R. Sarmidi, "Effect of solvent and initial water content on (R, S)-1-phenylethanol resolution," Enzyme and Microbial Technology, vol. 38, no. 3-4, pp. 551-556, 2006.

[37] Y. Liu, Q. Jin, L. Shan, Y. Liu, W. Shen, and X. Wang, "The effect of ultrasound on lipase-catalyzed hydrolysis of soy oil in solvent-free system," Ultrasonics Sonochemistry, vol. 15, no. 4, pp. 402-407, 2008. 
[38] B. D. Ribeiro, M. A. Z. Coelho, and D. W. Barreto, "Production of concentrated natural beta-carotene from buriti (Mauritia vinifera) oil by enzymatic hydrolysis," Food and Bioproducts Processing, vol. 90, no. 2, pp. 141-147, 2012.

[39] Z. A. Jarjes, R. S. Mohammed, and A. G. Sulaiman, "Bioelectrode in mechanistic study of lipoxygenase with fatty acids from cooking palm oil," The Open Electrochemistry Journal, vol. 4, no. 1, pp. 13-19, 2012.

[40] R. C. Rodrigues and R. Fernandez-Lafuente, "Lipase from Rhizomucor miehei as a biocatalyst in fats and oils modification," Journal of Molecular Catalysis B, vol. 66, no. 1-2, pp. 15-32, 2010.

[41] M. J. Hernáiz, M. Rua, B. Celda, P. Medina, J. V. Sinisterra, and J. M. Sánchez-Montero, "Contribution to the study of the alteration of lipase activity of Candida rugosa by ions and buffers," Applied Biochemistry and Biotechnology, vol. 44, no. 3, pp. 213-229, 1994.

[42] S. Benjamin and A. Pandey, "Isolation and characterization of three distinct forms of lipases from Candida rugosa produced in solid state fermentation," Brazilian Archives of Biology and Technology, vol. 44, no. 2, pp. 213-221, 2001.

[43] A. Sadana, Biocatalysis Fundamentals of Enzyme Deactivation Kinetics, Prentice Hall, Englewood Cliffs, NJ, USA, 1991.

[44] I. Babicz, S. G. F. Leite, R. O. M. A. de Souza, and O. A. C. Antunes, "Lipase-catalyzed diacylglycerol production under sonochemical irradiation," Ultrasonics Sonochemistry, vol. 17, no. 1, pp. 4-6, 2010.

[45] J. K. Satyarthi, D. Srinivas, and P. Ratnasamy, "Hydrolysis of vegetable oils and fats to fatty acids over solid acid catalysts," Applied Catalysis A, vol. 391, no. 1-2, pp. 427-435, 2011.

[46] L. S. Chua, M. Alitabarimansor, C. T. Lee, and R. Mat, "Hydrolysis of virgin coconut oil using immobilized lipase in a batch reactor," Enzyme Research, vol. 2012, Article ID 542589, 5 pages, 2012.

[47] C. Pizarro, M. C. Brañes, A. Markovits et al., "Influence of different immobilization techniques for Candida cylindracea lipase on its stability and fish oil hydrolysis," Journal of Molecular Catalysis B, vol. 78, pp. 111-118, 2012.

[48] L. Batistella, M. K. Ustra, A. Richetti et al., "Assessment of two immobilized lipases activity and stability to low temperatures in organic solvents under ultrasound-assisted irradiation," Bioprocess and Biosystems Engineering, vol. 35, no. 3, pp. 351-358, 2012.

[49] D. Y. Kwon, H. N. Song, and S. H. Yoon, "Synthesis of mediumchain glycerides by lipase in organic solvent," Journal of the American Oil Chemists' Society, vol. 73, no. 11, pp. 1521-1525, 1996.

[50] C. S. Chen and C. J. Sih, "General aspects and optimization of enantioselective biocatalysis in organic solvents: the use of lipases," Angewandte Chemie International Edition, vol. 28, no. 6, pp. 695-707, 1989.

[51] S.-J. Kuo and K. L. Parkin, "Solvent polarity influences product selectivity of lipase-mediated esterification reactions in microaqueous media," Journal of the American Oil Chemists' Society, vol. 73, no. 11, pp. 1427-1433, 1996.

[52] L. A. Lerin, A. Richetti, R. Dallago et al., "Enzymatic synthesis of ascorbyl palmitate in organic solvents: process optimization and kinetic evaluation," Food and Bioprocess Technology, vol. 5, no. 3, pp. 1068-1076, 2012.

[53] E.-T. Phuah, O.-M. Lai, T. S.-Y. Choong, C.-P. Tan, and S.-K. Lo, "Kinetic study on partial hydrolysis of palm oil catalyzed by Rhizomucor miehei lipase," Journal of Molecular Catalysis B, vol. 78, pp. 91-97, 2012.
[54] N. López, M. A. Pernas, L. M. Pastrana, A. Sánchez, F. Valero, and M. L. Rúa, "Reactivity of pure Candida rugosa lipase isoenzymes (Lip1, Lip2, and Lip3) in aqueous and organic media. Influence of the isoenzymatic profile on the lipase performance in organic media," Biotechnology Progress, vol. 20, no. 1, pp. 65-73, 2004.

[55] D. Rooney and L. R. Weatherley, "The effect of reaction conditions upon lipase catalysed hydrolysis of high oleate sunflower oil in a stirred liquid-liquid reactor," Process Biochemistry, vol. 36, no. 10, pp. 947-953, 2001.

[56] Y. Meng, G. Wang, N. Yang et al., “Two-step synthesis of fatty acid ethyl ester from soybean oil catalyzed by Yarrowia lipolytica lipase," Biotechnology for Biofuels, vol. 4, no. 1, article 6, 2011. 

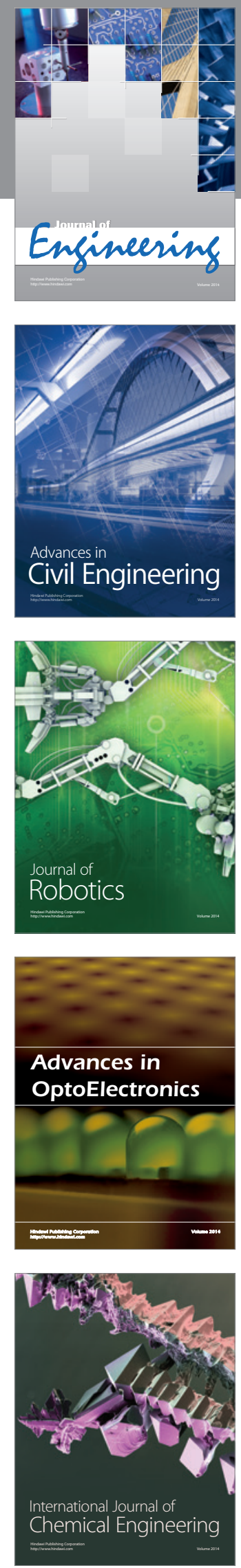

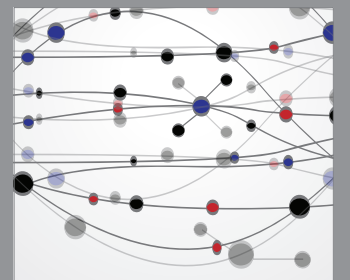

The Scientific World Journal
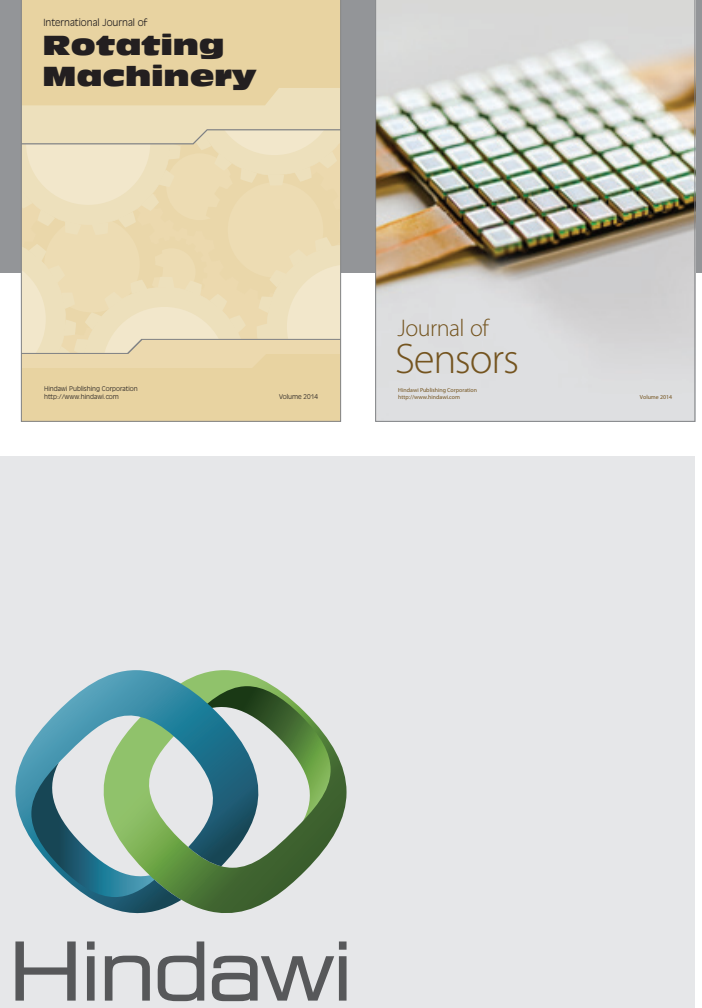

Submit your manuscripts at http://www.hindawi.com
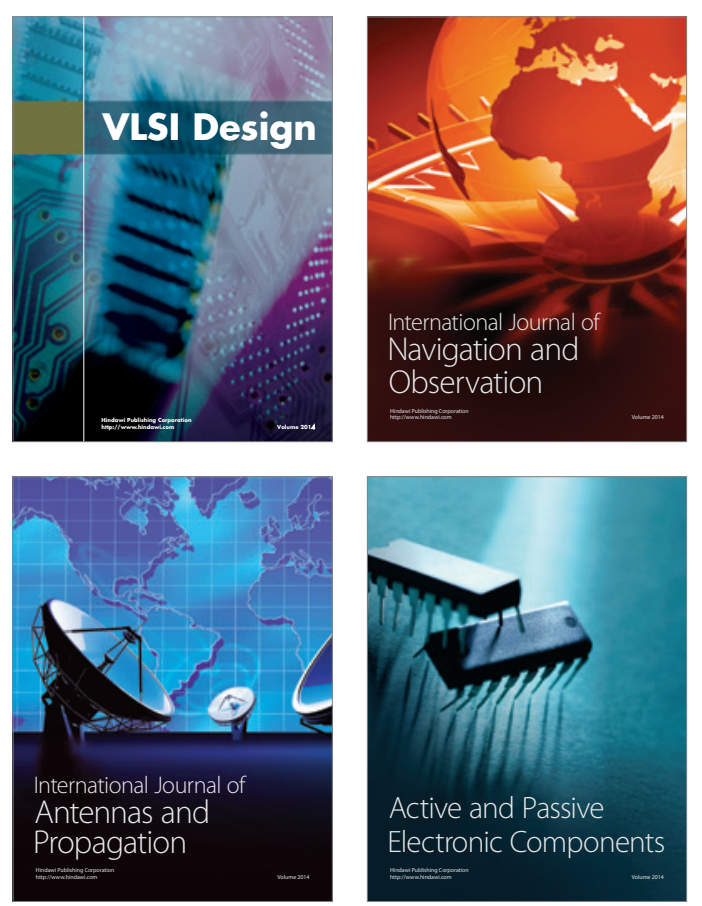


Journal of

Control Science

and Engineering
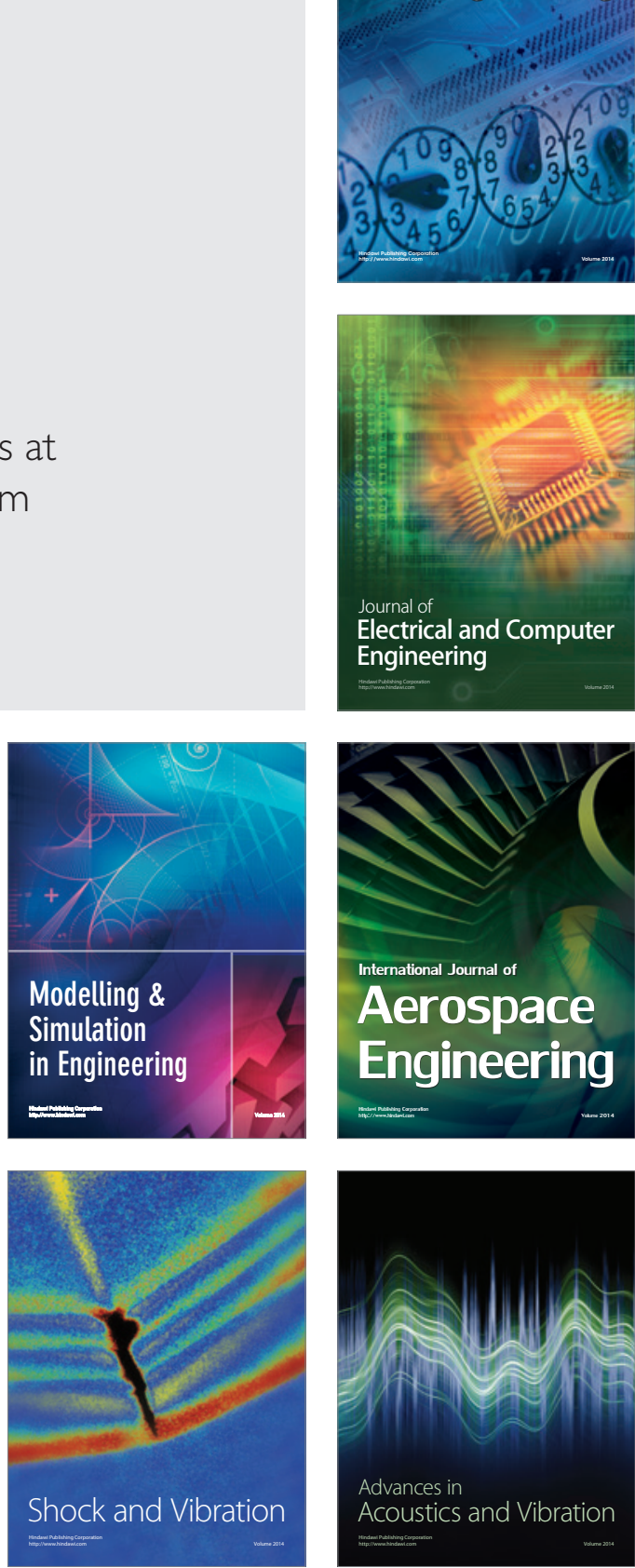